\title{
Cidadania e direitos dos jogadores de futebol na Democracia Corinthiana
}

CDD. 20.ed. 796.05

796.33

http://dx.doi.org/10.1590/1807-55092014000300429

\author{
Mariana Zuaneti MARTINS* \\ Heloisa Helena Baldy dos REIS*
}

*Faculdade de Educação Física, Universidade Estadual de Campinas.

\section{Resumo}

Esta é parte de uma pesquisa mais ampla sobre a Democracia Corinthiana. Nesta, buscamos compreender de que maneira e em que medida a experiência alvinegra ampliou e construiu uma concepção de cidadania para seus jogadores. Assim, foi necessário identificar quais eram as reivindicações e conquistas dos jogadores que participaram da Democracia Corinthiana. Para tanto, utilizamos os depoimentos dos jogadores, em uma entrevista semi estruturada e nos principais jornais impressos de São Paulo, no periodo de 1981 a 1985, e comparamos com o debate teórico sobre cidadania proposto por T.H. Marshall. Concluímos que houve avanços em diversos elementos da cidadania dos jogadores de futebol, mas ainda se manteve a reafirmação de pressupostos do atraso, como o vínculo do passe, que torna o jogador uma mercadoria, não um cidadão.

Palavras-chave: Democracia Corinthiana; Cidadania; Jogadores de futebol; Sociologia do esporte.

\section{Introdução}

A Democracia Corinthiana pode ser compreendida como as duas gestôes do presidente Waldemar Pires à frente do Sport Club Corinthians Paulista, ocorridas entre março de 1981 e março de 1985. Neste período, foram estabelecidas formas menos autoritárias de gestáo do clube e da equipe de futebol, tornando possível a participação dos jogadores em processos de tomada de decisóes.

Este movimento emergiu no contexto histórico e político do final da década de 70 e o início dos anos 80, que foi marcado, no Brasil, pela ascensão de movimentos sociais e sindicais ${ }^{1-5}$. Os atores políticos desse período tinham como princípio articulatório o embate à ditadura militar, a partir da construção de um projeto que expandisse a ideia de cidadania e aprofundasse a democracia ${ }^{6}$. A concepção de cidadania forjada pelos movimentos sociais na década de 80 teve como implicação analítica, em primeiro lugar, a compreensão de que essa é construída historicamente e, portanto, deve ser contextualizada e analisada em seu processo de constituição à luz dos sujeitos históricos. Nesse contexto, a contribuição de T.H. Marshall ${ }^{7}$ sobre a cidadania como processo $^{8-9, a}$ apresenta-se relevante. Em segundo lugar, entende-se a cidadania como parte de um conflito, e as conquistas relativas a ela estarão sempre sujeitas a mudanças. Nesse sentido, partindo dessa concepçáo não uniforme e como expoente de disputas, buscamos compreender de que maneira e em que medida a Democracia Corinthiana ampliou e construiu a cidadania de seus jogadores. Assim, foi necessário identificar quais eram as reivindicaçóes e conquistas dos jogadores do Corinthians que atuaram no período da Democracia Corinthiana.

\section{A Democracia Corinthiana no contexto da "nova cidadania"}

No contexto dos embates pela democratização brasileira, emergiu no Sport Club Corinthians Paulista a Democracia Corinthiana. Em geral, define-se este movimento a partir de um de seus procedimentos, isto é, a possibilidade de os jogadores de futebol votarem as questóes referentes ao departamento de futebol ${ }^{10}$. Para nós, esta experiência pode ser analisada a partir de várias facetas: como um projeto de modernização da gestão do clube alvinegro; como vanguarda na promoção do marketing esportivo, aproveitando-se da disjuntiva "democracia versus ditadura"; como a participaçáo de jogadores de um clube de futebol nas lutas do movimento político 
das "Diretas-Já"; ou mesmo como a organização destes sujeitos em torno de algumas demandas acerca de suas próprias condiçóes de trabalho. Buscamos entendê-la, nesse caso, a partir de seu significado concreto, que uniu essas diversas facetas de análise, focando, em especial, o conteúdo que ela desenvolveu a partir da demanda dos jogadores por transformaçôes em seu processo de trabalho. Entretanto, antes de nos determos nesta vertente, é fundamental olharmos para a conjuntura histórica no interior da qual ela se desenvolveu.

O movimento grevista de 1978, iniciado no ABC Paulista, segundo SADER ${ }^{1}$, significou um novo período na história brasileira, marcado pela emergência dos movimentos sociais e de novos sujeitos, que repensavam práticas, conceitos, identidades, vínculos, matrizes discursivas e sentidos de coletividade pertencentes ao momento anterior. $\mathrm{O}$ autor afirma que tais movimentos demarcavam o surgimento de um "comportamento coletivo de



De acordo com $\mathrm{PAOLI}^{2}$, existia nesse período uma dualidade constitutiva do surgimento dos movimentos sociais que era advinda, de um lado, do novo tipo radical de imaginação política, capaz de se contrapor à crise política do momento e, de outro, de uma efervescência contestatória. Isso porque os movimentos foram respostas ao caráter desagregador e autoritário do Estado brasileiro, ao mesmo tempo em que inauguraram um novo referencial de análise, a própria

\section{Método}

Os dados dessa pesquisa foram produzidos a partir de uma entrevista semi estruturada e depoimentos concedidos pelos jogadores do Corinthians aos veículos de comunicaçáo impressos no período de Março de 1981 a Maio de 1985. Realizamos o levantamento dessas fontes nos periódicos esportivos dos dois principais jornais do estado de Sáo Paulo $(O$ Estado de S. Paulo e a Folha de S. Paulo), e a Revista Placar, já que essa apresentava um interesse grande pelo movimento, expresso em diversos editoriais ${ }^{\mathrm{b}}$. Esses materiais foram escolhidos por serem as principais referências da imprensa esportiva, os principais jornais do Estado de São Paulo e por contemplarem visóes distintas, tanto de apoio como de oposição ao movimento corinthiano. A entrevista semi estruturada realizada com uma liderança da Democracia Corinthiana, o jogador Wladimir, noção de movimentos sociais, "cuja especificidade é a de reivindicarem exatamente sua diferença e direito de proclamá-la como base de sua própria constituição como coletivo em movimento" ${ }^{2}$ (p.26).

Como criação desses movimentos sociais, emerge a construção de uma nova cidadania, definida por DAGNINO $^{11}$ a partir de alguns pressupostos gerais: a) a redefinição da ideia de direitos, a partir da noção do "direito a ter direitos", a partir da qual a esfera da cidadania não pode mais ser previamente definida, pois deve ser advinda da luta cotidiana, que possibilita a criação de novos direitos; b) a noção de que trata-se de uma cidadania que não quer ser incorporada por um agente dominante, mas requer a constituiçáo de sujeitos sociais ativos e, nesse sentido, vem de "baixo para cima"; c) a criaçáo de uma nova proposta de sociabilidade, calcada na difusão de cultura de direitos, questão fundamental que torna o sujeito cidadão; d) a importância dada não simplesmente à "inclusão", mas ao "direito de participar efetivamente da própria definição do sistema"11 (p.109).

A partir dessa noçáo de cidadania, que os movimentos sociais criavam uma nova sociabilidade pautada na reivindicação de novos direitos, politizando os espaços antes silenciados da esfera privada ${ }^{1}$. Nesse contexto, até mesmo o futebol pode ser entendido como uma esfera pública para a visibilidade das demandas de contrapúblicos subalternos ${ }^{12}$, questionando a ordem social vigente, e atuando na constituição de uma nova hegemonia. forneceu maiores informações sobre as articulaçóes e conquistas do movimento ${ }^{c}$.

Para a análise dos depoimentos, apoiamo-nos nas consideraçóes do historiador Jacques Le Goff. O autor salienta que "tendo em vista que todo documento é ao mesmo tempo verdadeiro e falso, trata-se de pôr à luz as condiçôes de produção e de mostrar em que medida o documento é um instrumento de poder" 13 (p.525). Por isso, a escolha dos periódicos esportivos cumpriu em nossa pesquisa o papel de colocar em ordem ideias recorrentes e em conflito opiniōes diversas sobre o assunto. Após este levantamento, separamos todas as reportagens que possuíam relatos de conquistas e demandas reivindicadas pelos jogadores durante a Democracia Corinthiana, bem como os extratos da entrevista que se remetiam a essa temática. Em seguida, os organizamos para analisá-los de acordo 
com as categorias de direitos identificadas como constitutivas da cidadania, sendo elas direitos civis, políticos e sociais, atendendo a proposta de Marshall. A partir dessa organização, nossa análise se deteve em confrontar os relatos dos jogadores sobre estes direitos

\section{Resultados e discussão}

\section{A construção da cidadania dos jogadores de futebol na Democracia Corinthiana}

A Democracia Corinthiana pode ser entendida como elemento de questionamento do autoritarismo e do paternalismo no futebol, na medida em que servia como espaço de contraponto à hierarquização presente na arena esportiva, que impedia que o jogador pudesse comandar a própria vida ${ }^{14}$. Para o jogador Sócrates, uma das principais lideranças da experiência aqui tratada, esta possibilidade se apresentava como inédita, já que o jogador de futebol podia constituir-se enquanto cidadáo, pois

Por tradição, o futebol brasileiro é meio retrógrado e paternalista. Apegados ao poder, os dirigentes dos clubes e federaçôes procuraram alienar os jogadores e tratá-los como escravos. Desde que Charles Miller introduziu o futebol no Brasil, poucos foram os momentos nos quais os jogadores lutaram por melhores condições de trabalho. Mais raras ainda foram as lutas das quais os atletas saíram vitoriosos. Em um país como o Brasil, dificilmente o jogador de futebol é tratado como profissional e cidadão, com direitos e deveres, com liberdade e responsabilidade ${ }^{10}$ (p.18).

Este trecho demonstra as pré-condiçôes de constituição da cidadania para esses jogadores corinthianos. Entretanto, impera a necessidade de explicitar como isso ocorreu concretamente, de modo a compreender qual foi a constituição objetiva dessa forma de cidadania.

Abordar a atuação dos jogadores da Democracia Corinthiana na conquista de seus direitos é importante, porque explicita dois elementos: em primeiro lugar, quais foram os limites e as possibilidades desse movimento radical, na medida em que demonstrou um exemplo de como os jogadores de futebol poderiam ter melhores condiçóes de trabalho; em segundo lugar, a compreensão da formação de uma identidade coletiva efetiva dos jogadores em torno da Democracia Corinthiana ${ }^{15, d}$. com a discussão empreendida por Marshall acerca do desenvolvimento destes. Com isso, apontamos os ganhos concretos, as possibilidades e os limites da experiência corinthiana, indicando os seus legados para os direitos da categoria de jogadores de futebol.

Os significados de democracia para os sujeitos da Democracia Corinthiana, estavam subentendidos tanto a partir de uma dimensão mais individual - no caso das "liberdades", como de não se concentrar antes das partidas; quanto na dimensão coletiva da participação - com relação ao direito à palavra e à opinião, ou mesmo em um caso mais concreto do acesso a alguns direitos trabalhistas ${ }^{16}$. Esta multiplicidade de visóes se relaciona com sentidos possíveis de uma cidadania moderna, descritos por T.H. MARSHALL ${ }^{7}$. O autor afirmou que a cidadania é constituída por três elementos: o civil, o político e o social. Segundo Saes ${ }^{8}$

São direitos civis, para Marshall, aqueles direitos que concretizam a liberdade, individual, como os direitos à livre movimentação e ao livre pensamento, à celebração de contratos e à aquisição ou manutenção da propriedade; bem como o direito de acesso aos instrumentos necessários à defesa de todos os direitos anteriores (ou seja: o direito à justiça). São direitos políticos, segundo Marshall, aqueles direitos que compõem, no seu conjunto, a prerrogativa de participar do poder político; prerrogativa essa que envolve tanto a possibilidade de alguém se tornar membro do governo (isto é, a elegibilidade) quanto a possibilidade de alguém escolher o governo (através do exercício do voto). Finalmente, os direitos sociais equivalem, para Marshall, à prerrogativa de acesso a um mínimo de bem estar e segurança materiais, o que pode ser interpretado como o acesso de todos os indivíduos ao nível mais elementar de participação no padrão de civilização vigente (p.3).

Apresentando as diversas dimensóes que a cidadania alcançou na Democracia Corinthiana, pretendemos evidenciar os diferentes sentidos e os sólidos efeitos que o termo em questão obteve dentro do grupo, explicitando, entáo, as diferentes demandas do movimento alvinegro, no sentido de constituir a identidade coletiva deste e compreender como foi expandido o sentido da cidadania para os jogadores do Corinthians. 


\section{Direitos civis na Cidadania Corinthiana}

No modelo de Marshall os direitos civis são o elemento fundador da cidadania moderna, por serem eles os garantidores dos direitos de liberdade individuais, inaugurando uma justiça que seria, pelo menos em tese, estendida a todos. Um dos pilares dos direitos civis é o direito ao livre contrato, criado nos primórdios do capitalismo industrial, mas ainda uma questão candente na década de 80 para os jogadores de futebol. O "passe" dos jogadores ainda os vinculava a um sistema de trabalho que não prezava pelo "livre" contrato (livre no sentido de o trabalhador poder se desvincular de seu empregador conforme sua própria vontade). Ainda que a ideia de "ser verdadeiramente livre" seja passível de discussão - tendo em vista os condicionantes capitalistas que foram impostos à população, na urbanização, como a submissão a condiçóes de trabalho extremamente precarizadas ${ }^{9}$ - o fato é que até o final da década de 90, os jogadores de futebol dependiam da vontade de seu empregador para poderem se mover de um local de trabalho ao outro. O caso de Afonsinho é emblemático para ilustrar as relaçóes de trabalho naquele período histórico: se o jogador náo se acertava com o clube, quer em período de renovação de contrato ou por qualquer outro motivo, ele poderia passar meses sem jogar, e seu passe era, consequentemente, desvalorizado ${ }^{17}$. Sócrates relatou esse caso como um dos fatores que o fez, no Corinthians, começar a discutir relaçôes de trabalho mais justas. $\mathrm{O}$ jogador também trabalhou para atrasar a negociação da renovação de seu contrato em 1980, para que seu passe se desvalorizasse e ele pudesse comprá-lo, de modo a possuir "sua carta de alforria e não ser mais propriedade do clube corintiano" 10 (p.26). Essas duas situaçóes revelam um problema dos jogadores naquele período. Wladimir, outra liderança da Democracia Corinthiana, que foi presidente do Sindicato dos Atletas Profissionais (de 1984 a 1986), tratou, em nossa entrevista dessa questão, do "passe livre", identificando-a como um dos pontos centrais de sua gestão no sindicato

Nós temos uma parceria com a escola, a forma $\mathrm{E}$ a gente tinha uma situação que nos incomodava muito que era a questão do vínculo com o clube. Naquela época era uma lei escravagista. Nós não tínhamos liberdade de ir e vir. Terminava meu contrato, eu ficava negociando com o clube. Se eu ficasse seis meses negociando com o clube, eu ficava seis meses sem jogar e sem receber. E ficava aquela briga de você pede tanto, o clube oferece tanto. E tinham vários jogadores que ficavam sem jogar e sem receber por conta dessa situação. Porque era uma lei escravagista. $\mathrm{O}$ contrato de gaveta fazia com que eles [os clubes] tivessem poder sobre nossa vidaf.

$\mathrm{Na}$ Democracia Corinthiana, entretanto, a situaçáo do passe do jogador era tratada de forma contraditória. Por mais que alguns de seus sujeitos colocassem-na como uma questão fundamental, Adilson Monteiro Alves, vice-presidente alvinegro $\mathrm{g}$, afirmava que renovar o contrato com ele era mais difícil que com Vicente Matheus, uma vez que, em função de sua forma empresarial de gerir pautada pela necessidade de orçamentos superavitários, ele não se rendia a qualquer proposta reivindicada pelos jogadores. É verdade que ele trabalhou para valorizar alguns jogadores que estavam há muito tempo no clube, como Wladimir e Biro-Biro, mas não deixava de ter como perspectiva a visão do jogador como parte do patrimônio liquido do clube ${ }^{18}$.

Apesar de não ter conseguido combater o poder exacerbado dos clubes no momento de constituição dos vínculos trabalhistas, os jogadores pontuavam outra forma de liberdade, como uma das primeiras questóes a ser relatada publicamente em seus comentários à imprensa. Na vitória do campeonato paulista de 1982, por exemplo, as falas de Sócrates com relação ao título se remetiam à questão da liberdade permitida dentro do grupo. Segundo Sócrates, a conquista de títulos representava a luta por maior liberdade, na medida em que a obtenção da vitória no campeonato paulista significaria a legitimaçáo da gestão menos autoritária que se desenvolvia no Corinthians $^{19}$. O jogador também afirmava que a Democracia Corinthiana questionava pilares importantes do futebol, como a obrigatoriedade de concentração antes das partidas. Essa demanda dos jogadores estava sendo acatada pelo técnico, que afirmava que a partir do ano seguinte a concentração não seria mais obrigatória ${ }^{19}$. O presidente Waldemar Pires reconheceu o título de 1982 como uma vitória da abertura, pois teria proporcionado a todos o direito de opiniáo e de participar das decisóes ${ }^{19}$.

A questáo da não obrigatoriedade da concentração tornou-se uma das conquistas da Democracia Corinthiana, no que tange às liberdades dos jogadores. A questão da concentração em si pode ser identificada como a necessidade de um clube de futebol controlar o tempo disponível, de lazer, de seus jogadores. Por isso, o ângulo que estamos abordando refere-se à importância de o atleta poder decidir sobre a gestáo de seu tempo livre. Referente a isto, Wladimir destacou a maneira como o uso de 
bebidas alcoólicas pelos atletas era tratado: eles não tinham que ocultar esse fato. Tal quadro era incômodo para a imprensa esportiva e para os conselheiros do Corinthians que faziam parte da oposição à Democracia Corinthiana, imputando ao consumo dessas bebidas adjetivaçôes como "baderna" e "irresponsabilidade”. Para alguns jogadores, a liberdade de ingestão de álcool significava exatamente o contrário, uma demonstração de responsabilidade, uma vez que a equipe teria que se responsabilizar sobre as consequências de suas açóes:

Todos os assuntos que nos diziam respeito, a gente decidia coletivamente. A concentração, por exemplo, todo mundo foi ouvido. O consenso foi que a concentração fosse facultativa. Os solteiros teriam que concentrar. Os casados, só iriam para a concentração quem quisesse. Os solteiros achavam confortável concentrar porque era o momento em que eles descansavam, se alimentavam melhor. E os casados, alguns concentravam, o Leão, o Biro-Biro, o Zenon. Então, isso foi facultativo. Eu acho concentração um saco. Sempre achei. Eu comia a comida da minha mãe, que era melhor. (...). Foi maravilhoso porque a gente sabia que se a gente perdesse, estava na roça, ia acabar. Iam atribuir tudo a não concentração. $\mathrm{O}$ pessoal terminava o treino e ficava no Bar da Torre, lá no Parque São Jorge, e tomavam uma cerveja, o Sócrates, o Juninho, Casagrande. A gente fazia tudo às claras, não tinha nada para esconder de ninguém. E incomodava, sobretudo a imprensa, mídia conservadora (Wladimir em entrevista).

Essa liberdade que se forma com o advento da Democracia Corinthiana dizia respeito ao atleta poder decidir sobre seu tempo. Conforme Morais ${ }^{20}$, no capitalismo, em especial com o advento do fordismo e taylorismo, surgiram dispositivos culturais que, de forma velada, tentavam controlar o que o trabalhador fazia em seu tempo de não trabalho - de forma a não atrapalhar a sua produtividade no subsequente dia de trabalho. Entretanto, para o jogador de futebol isso acontecia de forma extremamente controlada, colocando-o sob as rédeas de seu patrão, mesmo no período de tempo de não trabalho. Abrir a possibilidade dos jogadores construírem outras formas de sociabilidade em seu tempo disponível pode permitilos uma maior autonomia no lazer, o acesso a bens culturais, discussôes coletivas, diversão, organização sindical, enfim, uma série de propostas e de atividades que podem, em alguma medida, atrapalhar o sentido de acumulação de capital para o clube.
Por outro lado, a dinâmica da escolha do tempo livre, imputa a responsabilidade sobre o uso dele, conforme a própria fala de Wladimir apontou. Segundo Marshall ${ }^{7}$, essa também é uma das decorrências das liberdades provindas dos direitos civis, porque não é uma relação apenas de benefícios. $\mathrm{O}$ autor ressalta que os direitos civis envolvem também obrigações de contrato, pois, além da liberdade individual, há na dinâmica de negociação, uma preocupação com o bem estar dos demais, que deve ser respeitado.

Além da possibilidade de usufruir o tempo disponível de forma mais autônoma, conforme esta fala Wladimir indica, o jogador ainda enfatizou a possibilidade de poderem falar sobre isso abertamente. Esta pode ser vista também como mais um dos direitos relacionados à esfera civil da cidadania, pois permitiu que os jogadores de futebol pudessem se expressar mais livremente. Como veremos adiante, o direito de opinião e a liberdade de expressão ainda terão maior consequência no que tange à possibilidade de participação política, provinda dos direitos políticos. Todavia, ainda é importante ressaltar que durante a Democracia Corinthiana há uma embrionária constituição daqueles jogadores de futebol como intelectuais orgânicos, no interior de sua própria prática e na realidade social. Conforme o sentido gramsciano do termo, todos são intelectuais no exercício de sua profissão, ainda que nem todos exerçam tal função. Contudo, há uma camada dentre esses que dá homogeneidade e consciência aos demais, não apenas no campo profissional, mas social e político. São considerados orgânicos, porque fazem parte do próprio grupo ao qual conferem essa ordem intelectual e moral. Deste modo, a possibilidade de se expressarem sobre questóes controversas as quais antes os jogadores não possuíam direito de opinar é a emergência, ainda que de forma embrionária, da constituição de intelectuais orgânicos dentre a camada de jogadores de futebol, possibilitando que eles mesmos se configurassem como construtores, organizadores, 'persuasores permanentes' da constituição de uma nova ordem intelectual e moral ${ }^{21}$.

Contudo, conforme Marshall aponta acerca do desenvolvimento da cidadania inglesa, o status individual da cidadania que se estabeleceu no século XVIII, fundado nos direitos civis, disponibilizou o fundamento da igualdade, que por outro lado, permitiu que a desigualdade se consolidasse, pois, embora os homens fossem livres e iguais em "status", não o eram em poder. Dessa forma, para o avanço da cidadania e redução das desigualdades, eram 
necessários que outros elementos também estivessem combinados, como o político e o social. É nesta esfera do debate sobre a cidadania que ganhou visibilidade o desenvolvimento dos direitos políticos. Em seguida, abordaremos o desdobramento dos direitos civis sobre os políticos na Democracia Corinthiana.

\section{Avanço nos direitos políticos na Democracia Corinthiana}

No modelo de cidadania de Marshall, os direitos políticos surgem como um desdobramento dos direitos civis, na medida em que as liberdades possibilitaram também o direito à participação, de modo que o poder político não estivesse restrito a uma casta, mas que fosse passível de eleição e disputa. A consolidação dos direitos políticos, entretanto, percorrera um caminho mais extenso, uma vez que mesmo consolidados os direitos civis, a participaçáo política ainda era restrita a uma pequena parcela da população. Marshall centra como elemento materializador dos direitos políticos a aprovação da Lei do Sufrágio Universal. Segundo o autor, apenas quando se destina a possibilidade de todos votarem é que se efetiva o avanço para que o fator político deixe de ser substrato do poder econômico 7 .

$\mathrm{Na}$ experiência coritnthiana, a expansão do direito de voto a todos os jogadores para a tomada de decisóes no departamento de futebol, em conjunto com o direito à discussão e à opiniáo, se mostrou muito importante. Segundo Sócrates:

Com o tempo, nós passamos a exercer o direito do voto dentro do Corinthians. Este foi o mote que gerou a transformação de todo o processo de relacionamento. Originou até o nome: Democracia Corinthiana. Tudo por causa do direito de voto. Nós passamos a exercer uma forma de relacionamento no qual o voto era essencial ${ }^{10}$.

No Brasil, a perspectiva do voto individual é um elemento central constituinte da cidadania. Tal perspectiva é reforçada por Lamounier, ao demonstrar que a ditadura militar brasileira, por mais que tenha suspendido as votações diretas para a presidência da república, em nenhum momento aboliu as eleições ${ }^{22}$. Pelo contrário, a existência de votação para o legislativo e até para alguns cargos do executivo, por mais que restrita, foi uma constante durante os quase vinte anos do regime militar. Duas reflexôes se extraem daí: a importância do voto individual para os brasileiros e a de que este elemento considerado isoladamente não compreende necessariamente um sistema democrático.

Essa relação não necessária entre voto e democracia pode ser observada também pelo fato de esse processo depender bastante da presença do dirigente Adilson Monteiro Alves, proponente do sistema de votaçáo dentro do Corinthians. Por isso, náo podemos subdimensionar a importância dele, como principal elo deste processo, uma vez que sua derrota nas eleiçóes do clube de 1985 foi o ponto final para as possibilidades democráticas no interior do plantel.

As principais críticas feitas à Democracia Corinthiana eram que a mesma se tratava de uma democracia "de três ou quatro", conforme a imprensa paulista noticiava, fato que repercutiu principalmente durante a demissão do técnico Mário Travaglini ${ }^{23}$. Nesse momento, referiam-se ao intenso diálogo que existia entre Adilson Monteiro Alves, Sócrates, Casagrande e Wladimir. De fato, esse grupo mais articulado não era negado por seus integrantes. Adilson Monteiro Alves afirmou em uma entrevista à Revista Placar que existia uma vanguarda dentro do movimento, mas que a mesma foi diluída quando o projeto deu certo: em todo movimento há uma vanguarda que coloca posições para a massa. Mas, na medida em que a proposta se transformou em projeto aprovado pela maioria, essa vanguarda foi diluída dentro da massa. Mas há sempre pessoas que se entregam mais. Você só leva murro se puser a cara. Nós [Wladimir, Sócrates e Adilson, que estavam sendo entrevistados] aceitamos isso ${ }^{24}$.

A fala de Adilson Monteiro Alves é corroborada com o depoimento concedido por Wladimir, no qual ele declara que existia um núcleo duro da democracia, responsável pela não omissão dos demais jogadores do elenco. O jogador ressalta que, apesar de existirem os que conduziam o processo, durante uma votação todos tinham o mesmo peso, a partir daí a democracia se consolidaria:

Nenhum jogador se omitia, porque eles eram conduzidos pelo núcleo duro, a gente que acabou se expondo mais - eu, Casagrande e Sócrates - e daí diziam que era uma democracia de três ou quatro. E os caras, quando vinham perguntar alguma coisa, perguntavam para gente, e a gente falava. Todo mundo votava, tinha direito a voto. O Leão que quando chegou quis tensionar isso, dizendo que o voto dele tinha que valer mais que o do reserva (Wladimir em entrevista).

Entretanto, a própria condição de todos terem o mesmo peso de voto nos momentos de decisão foi rompida na contrataçáo do jogador Leão, já que, por decisão do dirigente Adilson Monteiro Alves, só foi consultado alguns jogadores - aqueles que tinham convivido com o goleiro na seleção brasileira, além do técnico e do preparador físico. 
Aí há o indício de uma forma diretiva de conduzir o processo. Deste modo, também podemos entender como se davam as articulaçóes da "vanguarda" da Democracia Corinthiana. Adilson Monteiro Alves se reunia com Wladimir, Sócrates e Casagrande, e estes se articulavam para pensar os rumos do time.

Não é nosso argumento reforçar a tese da democracia "dos três ou quatro", mas salientar a condução do processo por uma vanguarda dentro do grupo. Com isso, afirmarmos a ideia das diferentes intensidades e modos de participação que se concretizavam no grupo, uma vez que o papel de condução do processo era de alguns, mas outros também participavam de forma a legitimar a "vanguarda", ainda que passivamente, assim como aqueles que eram mais omissos. A Revista Placar publicou uma pesquisa sobre a opinião dos jogadores do Corinthians a respeito da Democracia Corinthiana. Nela, 62,25\% dos jogadores ouvidos admitiam ter participado ativamente da experiência democrática; $25 \%$ afirmavam participação passiva; e $12,5 \%$ de participação relativa ${ }^{25, i}$.

As dificuldades em fazer com que os direitos políticos se tornassem efetivos para conduzir a ampla participação nas decisóes são ressaltadas por MARSHALL $^{7}$. Para o autor, a efetivação dos direitos políticos dependia da diminuição das desigualdades provindas de outras esferas, como a econômica, no acesso à participação. Ademais, no caso dos trabalhadores, a experiência e o tempo de organização sindical seriam elementos fundamentais para que os direitos políticos conseguissem interferir concretamente na estrutura social. No caso da experiência corinthiana especificamente, a tentativa de expansão dos direitos políticos está relacionada a uma iniciativa de organização dos jogadores para participar de forma mais ampla na gestão do clube, por meio da disputa de vagas para o conselho deliberativo do clube. Então, tornou-se importante explorar o significado da presença dos jogadores no conselho deliberativo e na gestão do clube, observando ainda que isso significaria a participação dos mesmos na constituição e organizaçáo do Corinthians como empresa capitalista, no processo de modernização do futebol. Wladimir relata uma experiência de cogestão no time, relacionado-a a esse processo, a partir da participação de alguns jogadores no conselho deliberativo, que buscavam discutir os rumos do clube em conjunto com a diretoriaj.

A cogestão, essa oportunidade de participar dos meios de decisão do clube, era maravilhosa. Nós éramos conselheiros, eu, Zé Maria e o Gomes. Quem quisesse participar, poderia, nós, três só, que quisemos. Os outros achavam que não era conveniente. A gente se sentia muito satisfeito de poder contribuir para a vida política do clube (Wladimir em entrevista).

Entretanto, o próprio Wladimir, quando questionado sobre como fora essa participação, respondia que isso não tinha sido muito efetivo, porque foi menos do que a gente gostaria. Até porque as reuniōes do conselho eram às segundas-feiras, e era o dia que a gente estava de folga. A gente treinava a semana inteira e daí na segundafeira, teria que ir ao conselho. Então a gente não frequentava, e não frequentando, com três faltas consecutivas e sem justificativa, você perde o mandato. Então cassaram nosso mandato (Wladimir em entrevista).

Isso significou que ainda que os jogadores tivessem aumentadas suas possibilidades de direitos políticos no clube, podendo votar questóes referentes ao departamento de futebol e se eleger ao conselho, não houve participação direta dos jogadores na definição dos rumos da administração/ governo do clube.

A possibilidade de participação também ocorria no que diz respeito às questóes relacionadas à organização da equipe em campo. Esta modalidade fica evidente nas falas de Mario Travaglini, que afirmava que esse era seu jeito de treinar, com base no diálogo. Wladimir relatou, em entrevista, que esse foi o principal o avanço de direitos dos jogadores no Corinthians: foi basicamente a questão de discutir com o treinador como você joga e como você tem que jogar. Via de regra, o treinador se acha dono da verdade, e que você tem que jogar assim e assado, e às vezes ele não consegue entender qual é o seu potencial maior, sua característica. E daí você tem que argumentar com ele. Isso foi muito tranquilo com o seu Mario Travaglini. Ele entendia que tinha que ser dessa forma; na época seu Osvaldo Brandão também não aceitava. A maioria dos treinadores dizia que te queria jogando assim e ou você joga do jeito que ele quer, ou ele te tira do time e não existia essa relação, esse diálogo, que é muito legal, porque você consegue expor qual é o seu maior potencial.

Para Wladimir, esse era um processo visto como direito concreto alcançado dentro do clube. Deste modo, essa participação era a principal possibilidade dos atletas interferirem sobre seu próprio processo de trabalho. Interessante é que isso se configura, segundo estudiosos da pedagogia do esporte, como aspecto central para a performance excelente no esporte ${ }^{26}$. Portanto, essa é uma forma de participação desenvolvida que beneficia o desempenho da equipe dentro 
de campo, uma vez que estimula a inteligência geral do jogador e a compreensão cognitiva do desenrolar do jogo, ao passo que proporciona uma percepção maior sobre os conhecimentos táticos e a adequação das tomadas de decisóes ${ }^{1}$. Essa reflexão corrobora o que declarou Jair Picerni, ao conhecer o plantel corinthiano: "Esse pessoal tem QI altíssimo. Com uma conversinha só eles entendem tudo. Assim fica muito mais fácil" ${ }^{\prime 2}$. É importante ressaltar ainda que essa possibilidade só era alcançada com a concordância e permissão dos técnicos. Mário Travaglini tinha como característica esse modo menos autoritário de conduzir a equipe, ao contrário de Jorge Vieira. No momento de troca de técnico, era sempre ponderado se o candidato ao cargo estava ou náo de acordo com a forma de organizaçáo do plantel corinthiano.

Entretanto, por mais que as possibilidades provindas do processo de participação fossem, em geral, incorporadas harmoniosamente, em alguns momentos havia conflitos. De modo geral, quando as reivindicaçóes dos jogadores não entravam em contradição com os princípios da diretoria, havia uma conciliaçáo de interesses entre ambos os setores. Nos momentos de discórdia, o usufruto dos direitos políticos era ofuscado.

Um exemplo de tensão entre esses interesses se deu após a saída de Sócrates do clube, quando as opinióes do então técnico Jorge Vieira e Casagrande divergiram. A consequência foi a demissão do técnico, mas a diretoria também decidiu unilateralmente afastar o jogador por cerca de dois meses. Isso evidenciava a falta de autonomia dos jogadores nesse momento de tensão, uma vez que eles não tiveram a oportunidade de se manifestar ou votar sobre essa matéria.

Este episódio é importante para expor dois elementos. Em primeiro lugar, apesar de os dirigentes fazerem parte do coletivo que discutia as questôes na Democracia Corinthiana, não podemos igualar as formas de participação deles com a dos jogadores, pois eles possuíam um papel diretivo mais proeminente. Em segundo lugar, apesar de as decisôes terem sido encaminhadas de forma pacífica, essa nem sempre foi a maneira com que o processo se deu. No caso das divergências, a despeito da vontade da maioria, o que prevalecia era o poder da diretoria, que náo hesitava em usá-lo quando necessário, de forma autoritária inclusive. Isso demonstrou limitaçóes advindas de uma dependência da diretoria, que fez com que os jogadores ficassem impotentes ou paralisados em momentos de crise. Além disso, como Adilson Monteiro Alves não foi reeleito em 1985, naquele ano, as conquistas dos jogadores - como o diálogo, a concentração facultativa, dentre outras - esvaíram-se.
Essa situação demonstra um desdobramento das dificuldades apontadas por Marshall para efetivação dos direitos políticos. Segundo o autor, no caso da cidadania inglesa, para que estes direitos se desdobrassem em mudanças estruturais foi fundamental a organização nos sindicatos e a obtenção dos direitos sociais ${ }^{7}$. No caso da Democracia Corinthiana, até houve uma integração com os sindicatos dos jogadores de futebol, em especial por Wladimir ter presidido a entidade a partir de 1984 , contudo, essa participação não expandiu a experiência organizativa para o restante da categoria. Isso não significou que não houvesse avanços nos direitos sociais, como veremos adiante, mas conferiu uma expressão de fragilidade à organização dos jogadores corinthianos, como a situação anteriormente exposta demonstrou, deixando-os subordinados à diretoria para a efetivação de seus direitos políticos.

\section{Direitos sociais na Democracia Corinthiana}

Para Marshall, os primórdios dos direitos sociais - direitos entendidos como aqueles que garantem um patamar mínimo de igualdade entre os cidadáos - podem ser encontrados na "Poor Law", legislação elisabetana que regulamentava os salários num plano nacional ${ }^{7}$. No entanto, a partir dos direitos civis e da liberdade para exercer atividades econômicas, esta lei tornou-se um contra senso ao espírito do livre mercado e ao livre contrato e, por isso, entrou em decadência no século XVIII. Tal origem, entretanto, evidência uma das características do elemento social da cidadania, de se contrapor ao livre contrato, presente nos direitos civis. Com isso, o autor argumenta que o desenvolvimento da cidadania se direciona a uma diminuição da esfera civil (direitos individuais) em favor da esfera social (direitos coletivos). No que tange aos direitos sociais, dois deles são mais importantes para o autor, a educação e os direitos trabalhistas - este ficando mais evidenciado na Democracia Corinthiana.

No Corinthians, um ponto de grande discrepância entre os jogadores era o salário. A definição dos valores pagos aos jogadores ainda obedecia à regra da desigualdade, presente no futebol profissional. Ainda que alguns integrantes do time tivessem sido valorizados nas gestôes da Democracia Corinthiana, permanecia um abismo entre o maior salário, de Sócrates, e o de Wladimir, segundo maior valor. Entretanto, se a Democracia Corinthiana não acabou com as desigualdades e com os abismos 
salariais, ela ao menos tentou dar algumas respostas a estes. Em primeiro lugar, o prêmio oferecido pela diretoria aos jogadores por ganharem partidas e campeonatos era dividido igualmente entre todos aqueles relacionados para o jogo, independente de serem titulares ou reservas. Em segundo lugar, houve uma regulamentação das faixas salariais. Wladimir, em entrevista, relatou que

A Democracia Corinthiana determinou o seguinte, que haveria três níveis de salário. Pros iniciantes, que recém saem dos juniores, são primeiro contrato, vão ter uma remuneração; os intermediários, que são os titulares, que já têm um certo prestigio no elenco; e os "top's", que era o Sócrates, era o pessoal que tinha mais visibilidade. Então, nós tínhamos três níveis de salários (...). É lógico que o atleta quanto mais ele ganhar, mais ele quer. Se ele puder, tiver condição de reivindicar mais, é lógico que ele vai reivindicar mais.

Foi aprovado um escalonamento de salários, que, apesar de não acabar com as desigualdades, propunha regulamentá-las. Permaneceram os abismos entre o salário de Sócrates e os outros três níveis, mas, por essa via, atingiu-se um patamar que é próprio das burocracias, de um sistema de meritocracias que regulamenta as diferenças salariais e vincula mecanismos, ainda que formais, de possibilidades de ascensão.

Tal como na Democracia Corinthiana, o modelo de cidadania de Marshall não discrimina a existência de desigualdades. Em outras palavras, é parte de sua concepção o fato de um indivíduo possuir mais riqueza do que outro, mas é inadmissível que algum não possua sequer o mínimo suficiente para uma vida decente. Isto envolve um aumento na consciência social de tal modo que o objetivo passa a ser a diminuição das desigualdades provindas da classe social e não a extinçáo do sistema de hierarquias e classes.

Mas a diminuição na influência das classes nessa

forma não constitui um ataque ao sistema de

classe. Ao contrário, almejava, muitas vezes tanto

conscientemente, a tornar o sistema de classe menos

vulnerável ao ataque através da eliminação de suas consequências menos defensáveis. Aumentou o nível do piso no porão do edifício social e, talvez, o tornou mais higiênico do que antes. Mas continuou sendo um porão, os andares mais elevados do prédio não foram afetados ${ }^{7}$ (p.78-9).

Os direitos sociais, para o autor, proporcionam um mínimo pré-estabelecido para saúde, educação, moradia e renda, mas qualquer indivíduo que seja capaz de ultrapassar este piso é livre para fazê-lo. Tal mecanismo eleva o piso inferior, mas sem controlar o superior, o que não garante o estabelecimento de igualdade de níveis.

Transpondo essa ideia para o sistema de escalonamento salarial que ocorreu na Democracia Corinthiana, podemos verificar a mesma concepção que não se opõe ao estabelecimento de uma hierarquia, mas, ratifica uma estratificação que conforma as reivindicaçóes coletivas e a própria estrutura hierárquica de salários. Dentro de cada nível há uniformidade, mas, entre eles, situaçóes heterogêneas. Outro ponto sobre a questáo salarial levantada por Marshall é o entendimento de que os lucros dos donos das empresas - ou dos clubes de futebol - são altos, e por isso, eles deveriam ser mais bem divididos com os empregados. Com isso, o autor expóe o conflito entre os direitos sociais e o valor de mercado que não foi resolvido e mais, a solução para evitá-lo não parece disponível. O imperativo do livre mercado é o ganho privado, ao passo que o dever público é aquilo que move os direitos sociais. Por isso, o autor enfatiza a direção contrária ao direito privado que se verificou no desenvolvimento dos direitos sociais, demonstrando que ele depende da exposição do conflito e disputa travada pelos trabalhadores. Nesse sentido, a organização sindical e participação política dos trabalhadores representou uma experiência fundamental para o desenvolvimento desses direitos - confluência que, na Democracia Corinthiana, se desenvolveu de forma menos consolidada, como vimos anteriormente.

Segundo Marshall, a cidadania é um "status" concedido a membros integrais de uma comunidade que, a partir deste status, possuem igualdade em termos de direito e de responsabilidade. Na Democracia Corinthiana, observamos a constituiçáo de uma identidade coletiva, apoiada na redemocratização da sociedade brasileira, por um lado, e, por outro, em mudar algumas das condições de trabalho dos jogadores de futebol, o que constituiu uma expansáo da cidadania dos mesmos e, neste sentido, a elevaçâo destes ao "status" de sujeitos políticos. Além disso, a estratégia construída foi de diálogo com a diretoria, e até dependência dela, uma vez que Adilson Monteiro Alves fazia parte da vanguarda impulsionadora do movimento corinthiano.

Conforme nossa investigação demonstrou, houve avanços em parte aos direitos civis dos jogadores, no que diz respeito à possibilidade deles decidirem sobre o seu tempo livre, com a facultatividade da concentraçáo e o direito ao lazer dos mesmos relacionado ao consumo de bebidas alcoólicas. Houve uma expansão 
de seus direitos políticos dentro do clube, uma vez que eles tinham direito de opinar e participavam de parte das decisóes e se candidataram, bem como foram eleitos, ao conselho deliberativo do clube - o que foi definido por Wladimir como a cogestáo, processo que foi pouco efetivo. No que diz respeito aos direitos políticos de participação no sindicato, por mais que a diretoria do clube não criasse problemas, se desenvolvem desentendimentos que culminam nas incertezas relativas ao caso de Casagrande. Este caso ainda é emblemático quanto a não existência do direito do livre exercício de trabalho dos jogadores, já que Casagrande ficou dois meses sem jogar, sem poder ele mesmo decidir sobre seu futuro. Com relação à constituição de uma igualdade material, civilidade mínima dos direitos sociais, os jogadores conseguiram o estabelecimento de um piso salarial e de níveis de salários, entretanto, isso náo acabou com a desigualdade salarial existente dentro do clube.

Esses são os fundamentos de constituição da cidadania, forjadora da identidade coletiva destes jogadores, demarcada por alguns avanços nas condiçôes de trabalho, e também pela reafirmação de pressupostos do atraso, como o vínculo do passe, que acaba por tratar o jogador como uma mercadoria, e não como um cidadão.

\section{Notas}

a. São muitas as críticas à utilização dos pressupostos de Marshall para a compreensão da cidadania no Brasil. As principais críticas se resumem ao sentido "evolucionista" de sua concepção, seu sentido etnocêntrico, e a explícita subsunção da desigualdade à cidadania, de acordo com Saes e Behring e Boschetti. Vamos utilizar sua proposta atentando à divisão analítica constitutiva de sua definição.

b. Construímos um banco de reportagens extenso que continha depoimentos de jogadores publicados nesses veículos da imprensa. As reportagens trazem relatos dos sujeitos mais atuantes da Democracia Corinthiana, seus intelectuais orgânicos, como Sócrates, Wladimir, Casagrande, Juninho, os técnicos e o dirigente Adilson Monteiro Alves. São depoimentos concedidos em entrevistas coletivas tradicionais após jogos, comentando a situação do clube e, por conseguinte, dos jogadores naquele momento; ou de reportagens especiais (seja sobre o jogador específico ou sobre a Democracia Corinthiana). É importante ressaltar que esses depoimentos representam um recorte do que a imprensa considerava interessante publicar, por isso, a entrevista que realizamos com Wladimir cumpriu o papel de acrescentar mais detalhes ao que conseguimos buscar dos materiais publicados pelos meios de comunicação.

c. A entrevista semi estruturada foi realizada com questôes abertas como: "Como você definiria a Democracia Corinthiana?" e "Quais foram as conquistas do movimento?", "Que direito que a democracia corinthiana permitiu alcançar?" A entrevista foi realizada em 2012, agendada previamente, em local de preferência do entrevistado. Os procedimentos empregados na entrevista estão de acordo com os princípios éticos norteadores das Resoluçóes 196/96 e 251/97 do Conselho Nacional de Saúde.

d. O conceito de identidade coletiva é visto como analítico, para Melucci ${ }^{15}$, e é útil para descrever uma interação e definiçấo compartilhada das orientaçôes quanto à ação política e aos campos de oportunidades e constrangimentos nos quais esta toma lugar. Por isso, um elemento definidor da identidade é o conflito, momento no qual os atores sociais afirmam uma identidade a partir da forma como protestam, e reivindicam um espaço que seus oponentes os têm negado. De tal modo, os movimentos sociais buscam se apropriar de algo que reconhecem como seus. A identidade coletiva deve ser entendida como um sistema de relaçóes e representaçôes, isso porque ela representa uma série de vetores e de tensões que entram num processo de equilíbrio frágil, entre o que é a identidade declarada pelo ator e a sua representação entendida pela sociedade.

e. Segundo FlorenZANo ${ }^{17}$, em setembro de 1970, Afonsinho, então jogador do Botafogo de Futebol e Regatas, ao retornar ao time com cabelos compridos e de rosto barbado, é impedido de treinar e jogar, sob a justificativa de apresentar uma aparência "rebelde", pelo entâo técnico Zagallo. Após meses resistindo, e depois de quase desistir do futebol, o jogador decide entrar na justiça para reivindicar seu direito ao trabalho e ao seu passe. Em março de 1971, o jogador obtém o direito a seu passe, podendo escolher para qual clube iria trabalhar.

f. Wladimir em entrevista concedida a uma das autoras em 10/03/2012. A partir desse momento, quando nos referirmos a fala deste jogador em entrevista, fazemos menção a essa referência.

g. Adilson Monteiro Alves foi vice-presidente do Corinthians de novembro de 1981 a março de 1985. Ele era identificado como proponente das discussóes e votaçóes no departamento de futebol do clube. 
h. Vicente Matheus foi presidente do Corinthians de 1959 a 1961 e de 1972 a 1981.

i. Não sabemos a metodologia dessa pesquisa, ou mesmo quantos jogadores foram ouvidos. Apenas a utilizamos como uma base de referência, uma vez que essa foi realizada no curso de Ciências Sociais da PUC-SP, a qual demonstrou que a participação na Democracia Corinthiana não era homogênea ${ }^{25}$.

j. Temos que salientar que Sócrates não participara do Conselho Deliberativo por opção própria, uma vez que até teria se candidatado à chapa. Entretanto, como Sócrates “já tinha opiniâo formada acerca dos meios de eleição dos clubes no Brasil e [se] colocava contra a forma do processo. Já, naquele momento, tinha assumido a luta por eleiçóes diretas e livres" ${ }^{\text {”. }}$.

k. A tomada de decisão é um dos elementos do jogo inteligente, entendida como ter a compreensão da solução mais adequada taticamente às situaçóes de uma partida num determinado espaço de tempo ${ }^{26}$.

1. O afastamento de Casagrande gerou uma polêmica grande em função de ele ser dirigente sindical. Por isso, por mais que o Corinthians quisesse transferi-lo, não poderia, porque as leis trabalhistas garantiam estabilidade de emprego para sindicalistas.

\begin{abstract}
Citzenship and rights of the football players in Democracia Corinthiana

This paper is a part of a broader research about Democracia Corinthiana. In this one, we aim to analyse the means and in which way the corinthians' experience built and increased a citizenship conception to its football players. Therefore, it was needed to identify which were the players' claims and achievements by the time of Democracia Corinthiana. For this, it was conducted a semi structured interview with a Corinthians' football player and an historical research in the newspapers of largest circulation in São Paulo, and compared with the theorical debate about citizenship proposed by T.H. Marshall. It was concluded that there were advances in some of the citizenship elements, but it had been hold one conservative aspect, like the transfer fee, that makes the player a commodity, not a citizen.
\end{abstract}

KEY WORDS: Democracia Corinthiana; Citizenship; Football players; Sociology of sport.

\title{
Referências
}

1. Sader E. Quando novos personagens entram em cena. São Paulo: Paz e Terra; 2002.

2. Paoli MC. Movimentos sociais no Brasil: em busca de um estatuto político. In: Helmann M, organizador. Movimentos sociais e democracia no Brasil. São Paulo: Marco Zero; 1995.

3. Kowarick L. Movimentos urbanos no Brasil contemporâneo: uma análise da literatura. Rev Bras Ci Soc. 1987; 1. [citado fev. 2011]. Disponível em: http://www.anpocs.org.br/portal/publicacoes/rbcs_00_03/rbcs03_03.htm.

4. Bertoncelo E. A campanha das diretas e a democratização. São Paulo: Humanitas; 2007.

5. Fernandes F. Nova República? Rio de Janeiro: J. Zahar; 1986

6. Dagnino E. Políticas culturais, democracia e o projeto neo-liberal. Rev Rio Janeiro. 2005;15:45-65.

7. Marshall TH. Cidadania, classe social e status. Rio de Janeiro: Zahar; 1967.

8. Saes DAM. Cidadania e capitalismo: uma crítica à concepção liberal de cidadania. São Paulo: Instituto de Estudos Avançados, Universidade de São Paulo; 2000. (Caderno n.8).

9. Behring ER, Boschetti I. Política social: fundamentos e história. 9a ed. São Paulo: Cortez, 2011.

10. Sócrates GR. Democracia corinthiana: a utopia em jogo. São Paulo: Boitempo; 2002.

11. Dagnino E. Sociedade civil, participação e cidadania: de que estamos falando? In: Mato D, organizador. Políticas de ciudadanía y sociedad civil en tiempos de globalización. Caracas: Universidad Central de Venezuela; 2004.

12. Fraser N. Rethinking the public sphere: a contribution to the critique of actually existing democracy. ln: Robbins B, organizer. the phantom public sphere. Minneapolis: University of Minnesota; 1995.

13. Le Goff J. História e memória. Ferreira I, Leitão B, Borges SF, tradutores. 5a ed. Campinas: Editora da UNICAMP; 2003.

14. Florenzano JP. A democracia corinthiana: práticas de libertação no futebol brasileiro [tese]. São Paulo (SP): Pontifícia 
Universidade Católica; 2003.

15. Melucci A. A invençáo do presente: movimentos sociais nas sociedades complexas. Rio de Janeiro: Vozes; 2001.

16. Martins MZ. Democracia corinthiana: sentidos e significados da participação dos jogadores [dissertação]. Campinas (SP): Universidade Estadual de Campinas, Faculdade de Educação Física; 2012.

17. Florenzano JP. Afonsinho e Edmundo: a rebeldia no futebol brasileiro. São Paulo: Musa; 1998.

18. No Corinthians, jogador náo é mercadoria. Folha de S. Paulo, São Paulo. 27 mar. 1983;Esportes:29.

19. Valdemar Pires: a vitória da abertura. O Estado de S. Paulo, São Paulo. 14 dez. 1982;Esportes: 21.

20. Morais MAF. O tempo dos trabalhadores no trilho do capital: o processo de aceleração temporal na companhia Vale do Rio Doce/ MA [tese]. São Luís (MA): Universidade Federal do Maranhão; 2007.

21. Gramsci A. Os intelectuais e a organização da cultura. Rio de Janeiro: Civilização Brasileira; 1978.

22. Lamounier B. O 'Brasil autoritário' revisitado: o impacto das eleiçóes sobre a abertura. In: Stepan A, organizador. Democratizando o Brasil. Rio de Janeiro: Paz e Terra; 1988.

23. Travaglini sai, desanimado e desgastado. Folha de S. Paulo, São Paulo. 30 mar. 1983;Esportes:28.

24. A democracia se consolida. Rev Placar. 1983;672:14-7.

25. Os jogadores analisam a Democracia Corinthiana. Rev Placar. 1983;704:57.

26. Costa JC, Garganta J, Fonseca A, Botelho M. Inteligência e conhecimento específico em jovens futebolistas de diferentes níveis competitivos. Rev Port Ci Desporto. 2002;2:7-20.

27. Souza A. O Corinthians só se assustou no começo do clássico. Folha de S. Paulo, São Paulo. 20 ago. 1984;Esportes: 18.

\section{Agradecimentos}

Pesquisa financiada pela CAPES.

\begin{tabular}{r|l} 
ENDEREÇo & \\
Heloisa Helena Baldy dos Reis & \\
Faculdade de Educação Física & Recebido para publicação: 13/05/2013 \\
Universidade Estadual de Campinas & 1a. Revisão: 10/11/2013 \\
Av. Érico Veríssimo, 701 & 2a. Revisão: 27/02/2014 \\
13083-851 - Campinas - SP - BRASIL & Aceito: 03/03/2014 \\
e-mail: helobaldy@yahoo.com &
\end{tabular}

